\title{
PARAMETERS OF PROTEIN METABOLISM IN GOATS FED DIETS WITH DIFFERENT PORTION OF SUGARCANE BAGASSE
}

\author{
S.A. Ariyani, L.K. Nuswantara, E. Pangestu, F. Wahyono and J. Achmadi \\ Faculty of Animal and Agricultural Sciences, Diponegoro University, \\ Tembalang Campus, Semarang 50275- Indonesia \\ CorrespondingE-mail: sitianisa89@gmail.com
}

Received April 15, 2014; Accepted May 27, 2014

\begin{abstract}
ABSTRAK
Limabelas ekor kambing Jawarandu jantan digunakan untuk mengkaji pengaruh porsi ampas tebu dalam pakan terhadap beberapa parameter metabolisme protein. Ternak memiliki rerata bobot badan sebesar $18 \mathrm{~kg}$ dengan rerata umur 18 bulan. Ternak ditempatkan pada kandang metabolisme dan dialokasikan sesuai rancangan acak lengkap yang menerima tiga jenis pakan perlakuan, dengan porsi ampas tebu sebesar 15,25 , dan $35 \%$. Setelah delapan minggu masa adaptasi terhadap pakan dan lingkungan perlakuan, setiap kelompok perlakuan menjalani uji kecernaan pakan, dan pengambilan sampel cairan rumen. Parameter yang dikaji adalah kecernaan pakan, retensi nitrogen, fermentasi ruminal, dan ekskresi alantoin untuk mengestimasikan sintesis nitrogen mikroba. Data diuji dengan sidik ragam dan dilanjutkan dengan uji wilayah ganda Duncan. Konsumsi bahan kering dan protein menurun nyata $(\mathrm{P}<0.05)$ selaras dengan peningkatan porsi ampas tebu dalam pakan. Kecernaan dan retensi nitrogen tidak dipengaruhi secara nyata oleh perlakuan porsi ampas tebu. Perlakuan pakan tidak berpengaruh secara nyata terhadap konsentrasi amonia, VFA total, asetat, propionat, dan butirat rumen. Sintesis nitrogen mikroba dan efisiensi sintesis nitrogen mikroba tidak berubah nyata akibat perlakuan porsi ampas tebu dalam pakan.
\end{abstract}

Kata kunci: ampas tebu, sintesis nitrogen mikroba, kambing

\begin{abstract}
Fifteen Jawarandu male goats were used to study the effect of different portion of sugarcane bagasse in diets on some parameters of protein metabolism. Goats had average of body weight of $18 \mathrm{~kg}$ and aged at 18 months. Animals were housed in metabolic cages and were alloted to a completely randomized design receiving three experimental diets with sugarcane bagasse portions of 15,25 , and $35 \%$ (dry matter basis), respectively. After eight weeks of adjustment period to experimental diets and environment, each group of treatment was subjected to ten days of digestion trial, and followed by collection of rumen liquid samples. Parameters observed were feed digestibility, nitrogen retention, ruminal feed fermentation, and excretion of urinary allantoin to estimate microbial protein synthesis. Data were tested using one way analysis of variance, and followed by Duncan's mulitiple range test. Dry matter and protein intakes lowered $(\mathrm{P}<0.05)$ as the increasing of sugarcane bagasse in diets. Protein digestibility and retention were unaffected by the treatment of bagasse portion. The dietary treatment did not change ruminal ammonia, total VFA, acetate, propionate, and butyrate concentrations. Microbial nitrogen synthesis and efficiency of microbial nitrogen synthesis were unaffected by the dietary treatment.
\end{abstract}

Keywords: sugarcane bagasse, microbial nitrogen synthesis, goats 


\section{INTRODUCTION}

The effect of carbohydrate sources on protein metabolism in ruminants have been studied intensively to some extent. Many studies emphasized to clarify that increasing amount of carbohydrates those fermented in the rumen would enhance conversion of ruminal ammonia to microbial protein, thereby supporting protein supply for animal production. Wanapat et al. (2013) suggested that the use of carbohydrate and protein sources properly in a diet has positively impact for microbial synthesis in young dairy bull. Increasing concentrate proportion in grass hay based diet enhances urinary purine derivative significantly in goats (Cantalapiedra-Hijar et al., 2009). Processing of barley grain increases urinary purine derivatives slightly in rapidly growing lambs fed high nitrogen diets (Kiran and Mutsvangwa, 2007). Supplementation of barley grain enhances microbial protein synthesis in the rumen of steers fed low quality of forage (Marsetyo et al., 2006). Hristov et al. (2005) reported that provision of readily fermentable energy from dietary carbohydrate can lower ammonia concentrations in the rumen because ammonia uptake for microbial protein synthesis increased. Information about the effect of cellulolisic ration on protein metabolism in goats is rarely.

Sugarcane bagasse is the byproduct of sugarcane industry and characterized with high content of its structural carbohydrates. The digestibility of sugarcane bagasse is well known to be low in ruminants because hemicellulose and cellulose content are tightly linked to its lignin component (Ramli et al., 2005). Dietary cellulose and hemicellulose in the rumen are fermented to become volatile fatty acids which in turn providing carbon skeleton for microbial amino acid synthesis (Preston and Leng, 1987). Therefore, it is postulated that higher bagasse portion in a diet may lower synthesis of microbial protein. The goal of this experiment was to determine some parameters of protein metabolism in goats fed different portion of sugarcane bagasse. Such study may give information about the use of bagasse as fiber sources in a total mixed ration for goats.

\section{MATERIALS AND METHODS}

\section{Experimental Animal and Diet}

This experiment used fifteen Jawarandhu cross bred male goats with average age at 18 months old and average body weight of $18 \mathrm{~kg}$. Animals were housed in metabolic cages, and were randomly assigned to three dietary treatments as total mixed rations (TMR) that contained 15,25 and $35 \%$ of sugarcane bagasse, respectively (Table 1). All diets were designed to be isonitrogenous and isoenergy. The total mixed rations were given ad libitum, and drinking water was available for goats throughout the experimental period.

\section{Methods}

After eight weeks of adjustment period to experimental diets and environment, feces and urine from goats were collected for 10 days. These feces and urine samples were collected to determine of the nitrogen retention. Content of allantoin, a purine derivative, in collected urine samples were analysed to estimate microbial nitrogen synthesis. Sampling and handling procedure for urine samples were similar to that described by Marsetyo et al. (2006). After period of feces and urine sampling collection, sample of rumen liquid from each goat was collected through their mouth, 2 hours after feeding. These samples of rumen liquid were analyzed for determination of ruminal ammonia concentrations and volatile fatty acids (acetate, propionate, butyrate) content.

Nitrogen content in feed, feces, and urine were determined using kjeldahl method according to AOAC (1999). Concentration of $\mathrm{NH}_{3}$ in rumen liquid was assayed utilizing the method of Conway disc. Concentration of total VFA in rumen liquid was determined using water distillation method. Concentrations of acetate, propionate, and butyrate in rumen liquid were determined using method of gaseous liquid chromatography. Concentration of purine derivative, allantoin, in urine was assayed according to procedure of Chen et al. (1992). Allantoin content in urine goats was then used to estimate the microbial nitrogen synthesis in rumen. Data were tested using analysis of variance, and followed by Duncan's multiple range test.

\section{RESULTS}

Feed dry matter (DM) and protein intakes decreased $(\mathrm{P}<0.05)$ decreased with increasing the sugarcane bagasse portion in diet (Table 2). Feed crude protein $(\mathrm{CP})$ digestion and retention were 
not affected by the portion of sugarcane bagasse.

The portion of bagasse in diet did not affect significantly on the concentrations of ruminal ammonia $\left(\mathrm{NH}_{3}\right)$ and total volatile fatty acids (VFA). Ruminal propionate and butyrate concentrations slightly decreased, but not significantly with increasing of bagasse portion in diet. Ruminal acetate concentration slightly increased, but not significantly, with the increasing of bagasse portion in diet (Table 2).

Concentration of urinary allantoin was not affected by bagasse portion in diet (Table 2). Bagasse portion in diet did not affect significantly on the estimated microbial $\mathrm{N}$ synthesis in goat, though the estimated microbial $\mathrm{N}$ synthesis was slightly enhanced with the increasing of bagasse portion in the diet. Efficiency of microbial $\mathrm{N}$ synthesis was not affected by bagasse portion in the diet, however efficiency of microbial $\mathrm{N}$ synthesis was slightly enhanced with the increasing of bagasse portion in the diet.

\section{DISCUSSION}

\section{Feed Intake and Apparent Digestibility}

Goats are known well to be a browser animal, they have different feeding behavior, intake, diet selection, and rate of eating from other ruminants (Lu et al., 2005). Results of empirical study indicated that forage production from shrub trees are decreasing in the recent years because of plantation lands conversion for housing and other infrastructures. These facts highlight a need to explore unexploited resources diet for goat. Sugarcane bagasse based TMR could be an alternate diet to achieve feed availability throughout the year, especially for goats. However, the use of sugarcane bagasse as a fiber source in a TMR should be limited because of its fiber components. The occurance of fiber components in sugarcane baggase are tightly bond to lignin as lignocellulose and lignohemicellulose (Ramli et al., 2005). Intakes of feed dry matter, organic matter, and protein decreased with the increasing of bagasse portion in diets (Table 1). Pinos-Rodriguez et al. (2002) stated that increasing bulkiness of diet results in lower feed intake in ruminant. Moreover, greater cell wall content in a diet may cause lesser ruminal degradation, and slower digestion and passage rates (Cantalapiedra-Hijar et al., 2009).

Apparent digestibility of $\mathrm{CP}$ was not affected though DM and CP intakes lowered by bagasse portion (Table 2). The increase of concentrate proportion in a forage based diet did not affect on $\mathrm{CP}$ apparent digestibility in goats (CantalapiedraHijar et al., 2009) and in dairy bulls (Wanapat et al., 2013). There is some controversy regarding to the CP digestiblity when portion of dietary forage is increased, which is likely due to the type of ingredients used in some experiments (Lu et al., 2005; Kiran and Mutsvangwa, 2007). Moreover, in this study, the experimental diets were designed to isonitrogenous (Table 2). In other words, some feedstuffs were used in addition bagasse to get desired CP level and TDN level in the diets (Table 1).

Amounts of the retained $\mathrm{CP}$ were not affected significantly by bagasse portion in diets (Table 2). Some result studies showed that decreasing CP intake caused lower in nitrogen retention. Smaller CP intake with the increasing of bagasse portion in the diet may explain this result. Foster et al. (2009) reported that smaller amount of retained CP has been found in lamb fed warm season grass compared to that supplemented with legume hays or soybean meal. The nitrogen retention was smaller in goats with decreasing concentrate portion in diets (Cantalapiedra-Hijar et al., 2009). The experimental diets were designed to isonitrogeneous and it may result in similar retained $\mathrm{CP}$ among treatments.

\section{Ruminal Fermentation}

High fiber diet decreases digestible organic matter in rumen therefore lowering ruminal VFA concentration. In this study, samples of rumen liquid of goats were collected $2 \mathrm{~h}$ post feeding. Increasing portion of bagasse in the diet did not affect in total VFA concentration in goats (Table 2). There are greater fluctuations of VFA concentration over time after feeding in goats when fed hay grass than alfalfa hay (Cantalapiedra-Hijar et al., 2009). Hristov et al. (2005) reported that intraruminally introduction of corn dextrose produces the lowest of VFA concentration compared with those of intraruminally introductions of starch and NDF in dairy cows. However, high celluloytic diet elevates ruminal acetate concentration (Preston and Leng, 1987). Likewise, intraruminally introduction of NDF has higher acetate concentration than produced intraruminally introduction of corn dextrose in dairy cows (Hristov et al., 2005). Cantalapiedra-Hijar et al. (2009) clarified that the increasing of concentrate portion in the goat diets elevated propionate 
Table 1. Ingredients and Chemical Composition of Experimental Diets

\begin{tabular}{lrrr}
\hline & \multicolumn{3}{c}{ Portion of Sugarcane Bagasse in Diets (\%) } \\
\cline { 2 - 4 } & 15 & 25 & 35 \\
\hline Ingredients, \% of DM & & & \\
Sugarcane bagasse & 15.00 & 25.00 & 35.00 \\
Copra mill & 13.00 & 13.50 & 13.50 \\
Groundnuts shell & 7.00 & 3.50 & 2.00 \\
Molasses & 7.00 & 7.00 & 7.00 \\
Soybean meal & 7.00 & 9.00 & 11.00 \\
Rice bran & 14.50 & 11.00 & 10.50 \\
Coffee seed shell & 12.00 & 7.00 & 2.00 \\
Urea & 0.50 & 0.50 & 0.50 \\
Oil palm frond & 10.00 & 10.00 & 5.50 \\
Wheat pollard & 14.00 & 13.50 & 13.00 \\
Chemical composition, \% & & & \\
Crude protein & 12.26 & 12.44 & 12.19 \\
Extract ether & 6.17 & 5.99 & 5.30 \\
Crude fiber & 29.11 & 29.18 & 28.78 \\
Nitrogen free extract & 45.12 & 45.63 & 47.30 \\
Ash & 7.35 & 6.76 & 6.44 \\
Total digestible nutrients & 60.30 & 60.33 & 60.02 \\
Neutral detergent fiber & 62.38 & 63.16 & 63.45 \\
\hline
\end{tabular}

concentration and lowered acetate concentration. Table 2 showed that increasing the portion of bagasse in the diets did not affect on acetate and propionate concentration. Accordingly, ratio of acetate to propionate was also unaffected by treatment of bagasse portion in diets.

Low DM and CP intakes may decrease the amount of degradable nitrogen in rumen thereby lowering ammonia concentration. However, ruminal ammonia concentration was unaffected $(\mathrm{P}>0.05)$ by increasing portion of bagasse in the goat diets, though DM and CP intakes lowered significantly (Table 2). Treatment of bagasse portion in this study ensured that ruminal ammonia concentration was sufficient to maximize microbial synthesis as as stated by Cantalapiedra-Hijar et al. (2009). There is a contrary in this study results about the effect of increasing $\mathrm{CP}$ intake on ruminal ammonia concentration, which is likely due to the type of ingredients used and the time of sampling for rumen liquid. Increasing level of concentrate enhances ammonia concentration in both grass and alfalfa diets in goats, but the increase of ammonia concentration in alfalfa based diet was not as high as in the grass based diet (Cantalapiedra-Hijar et al., 2009). Similar results was also reported by Foster et al. (2009) that legumes and soybean meal supplementations increased ruminal ammonia concentration in sheep, though the elevated ammonia concentration in soybean meal supplementation was not as high as in legumes supplementation. Intraruminally introduction of NDF gave the highest ammonia concentration compared to those of starch and corn dextrose in dairy cows (Hristov et al., 2005). Wanapat et al. (2013) stated that carbohydrate sources and cotton seed meal level 
Table 2. Experimental Result of Sugarcane Bagasse based Diets for Goats ${ }^{1}$

\begin{tabular}{|c|c|c|c|}
\hline \multirow{2}{*}{ Items } & \multicolumn{3}{|c|}{ Portion of Sugarcane Bagasse in Diets (\%) } \\
\hline & 15 & 25 & 35 \\
\hline \multicolumn{4}{|l|}{ Feed Consumption } \\
\hline Dry matter, $\mathrm{g} / \mathrm{d}$ & $805.5 \pm 129.99^{\mathrm{a}}$ & $695.54 \pm 120.97^{\mathrm{ab}}$ & $605.38 \pm 77.11^{\mathrm{b}}$ \\
\hline Organic matter, $\mathrm{g} / \mathrm{d}$ & $748.52 \pm 120.31^{\mathrm{a}}$ & $646.13 \pm 112.38^{\mathrm{ab}}$ & $577.95 \pm 67.28^{b}$ \\
\hline Crude protein, $\mathrm{g} / \mathrm{d}$ & $99.11 \pm 15.93^{\mathrm{a}}$ & $82.67 \pm 17.54^{\mathrm{ab}}$ & $75.72 \pm 8.84^{\mathrm{b}}$ \\
\hline Apparent CP digestibility, \% & $76.59 \pm 2.78$ & $75.95 \pm \quad 4.27$ & $78.18 \pm 4.09$ \\
\hline $\mathrm{CP}$ retention, $\mathrm{g} / \mathrm{d}$ & $11.85 \pm 2.31$ & $10.44 \pm 1.89$ & $9.36 \pm 1.48$ \\
\hline $\mathrm{NH}_{3} 2 \mathrm{~h}$ post feeding, $\mathrm{mM}$ & $3.74 \pm 0.80$ & $4.96 \pm \quad 1.84$ & $4.90 \pm 1.02$ \\
\hline Total VFA $2 \mathrm{~h}$ post feeding, $\mathrm{mM}$ & $58.35 \pm 21.46$ & $64.96 \pm 26.21$ & $69.11 \pm 19.05$ \\
\hline Acetate, $\%$ of total VFA & $64.87 \pm 4.08$ & $65.37 \pm 3.45$ & $69.01 \pm 3.97$ \\
\hline Propionate, $\%$ of total VFA & $25.29 \pm 5.05$ & $25.07 \pm 2.86$ & $22.34 \pm 2.91$ \\
\hline Butyrate, $\%$ of total VFA & $9.84 \pm 1.17$ & $9.56 \pm 1.45$ & $8.65 \pm 1.52$ \\
\hline Urinary allantoin, $\mathrm{mmol} / \mathrm{d}$ & $2.33 \pm 0.36$ & $2.31 \pm 0.58$ & $2.22 \pm 0.45$ \\
\hline Microbial N synthesis, g/d & $0.50 \pm 0.26$ & $0.56 \pm \quad 0.42$ & $0.55 \pm 0.32$ \\
\hline Efficiency of Microbial $N$ synthesis ${ }^{2}$ & $0.17 \pm 0.12$ & $0.15 \pm 0.12$ & $0.14 \pm 0.10$ \\
\hline
\end{tabular}

${ }^{1}$ Values are means of five sheep in each group of experimental diet (mean $\pm S D ; n=5$ )

${ }^{2}$ Calculated from g microbial $\mathrm{N}$ synthesis/kg OM consumption

a,b Means within a row with different superscripts letter are significantly different: $\mathrm{P}<0.05$

did not change ruminal ammonia concentrations in young dairy bulls.

\section{Microbial Nitrogen Synthesis}

Measurement of urinary allantoin excretion has been employed in many studies as a noninvasive marker of microbial protein flow from rumen. Table 2 shows that an increasing portion of bagasse in the diets did not affect on amount of urinary allantoin excretion and efficiency of nitrogen synthesis $(\mathrm{P}>0.05)$ in goats. This is likely due to similar ruminal VFA and ammonia concentrations among treatments. Microbial protein synthesis needs VFA as carbon sceleton, and ammonia as nitrogen source (Preston and Leng, 1987). Wanapat et al. (2013) reported that ruminal VFA and ammonia concentrations were not affected by carbohydrate sources and cotton seed meal level in young dairy bulls, thereby urinary allantoin and efficiency of microbial nitrogen synthesis remain unchanged.

The microbial protein synthesis may be enhanced when there is an improvement in the quality of diet simultaneously with considerating of synchronization of nutrients degradatio in rumen. Marsetyo et al. (2006) reported that supplementations of barley and barley plus protein increased microbial protein synthesis and efficiency of microbial protein synthesis in steers. High concentrate supplementation for low quality forage based diet elevated microbial protein synthesis in dairy heifers (Lascano and Heinrichs, 2011). Moorby et al. (2006) suggested that increasing microbial protein synthesis supported enhancing milk yield in dairy cows when they fed on diets with lower forage to concentrate ratio. Concentrate supplementations for grass and alfalfa hay based diets caused enhancement in microbial protein synthesis and efficiency of microbial protein synthesis in goats (Cantalapiedra-Hijar et al., 2009). In this study, though the goat diets were designed to be isoenergy and isonitrogenous, aspect of synchronization of nutrients degradation in rumen 
was not considered well (Table 1).

\section{CONCLUSION}

Sugarcane bagasse portion at $25 \%$ in goat diet lowered dry matter and crude protein intakes, though nitrogen retention, ruminal feed fermentation, allantoin excretion and eficiency of microbial nitrogen synthesis were unaffected. It is suggested that the portion of bagasse in TMR for goat might not exceed to $25 \%$.

\section{ACKNOWLEDGMENTS}

This research project was partly funded by The Grant Program of Fundamental Research, Ministry of Education and Culture, Directorate General of Higher Education, DIPA No: 0596/023-04.2-16/13/2012.

\section{REFERENCES}

AOAC. 1999. Official Methods of Analysis. 17th ed. AOAC Int., Arlington, VA.

Cantalapiedra-Hijar, G., D. R. Yáñez-Ruiz, A. I. Martín-García and E. Molina-Alcaide. 2009. Effects of forage:concentrate ratio and forage type on apparent digestibility, ruminal fermentation, and microbial growth in goats. J. Anim. Sci. 87:622-631.

Chen, X.B., G. Grubic, E.R. Orskov and P. Osuji. 1992. Effect of feeding frequency on diurnal variation in plasma and urinary purine derivatives in steers. Anim. Prod. 55:185191.

Foster, J. L., A. T. Adesogan, J. N. Carter, A. R. Blount, R. O. Myer and S. C. Phatak. 2009. Intake, digestibility, and nitrogen retention by sheep supplemented with warm-season legume hays or soybean meal. J. Anim. Sci. 87:2899-2905.

Hristov, A. N., J. K. Ropp, K. L. Grandeen, S. Abedi, R. P. Etter, A. Melgar and A. E. Foley. 2005. Effect of carbohydrate source on ammonia utilization in lactating dairy cows. J. Anim. Sci. 83:408-421

Kiran, D. and T. Mutsvangwa. 2007. Effects of barley grain processing and dietary ruminally degradable protein on urea nitrogen recycling and nitrogen metabolism in growing lambs. J. Anim. Sci. 85:33913399.

Lascano, G. J. and A. J. Heinrichs. 2011. Effects of feeding different levels of dietary fiber through the addition of corn stover on nutrient utilization of dairy heifers precisionfed high and low concentrate diets. J. Dairy Sci. 94 :3025-3036.

Lu, C. D., J. R. Kawas and O. G. Mahgoub. 2005. Fibre digestion and utilization in goats. Small Rumin. Res. 60:45-52.

Marsetyo, D.P. Poppi and S.R. Mc Lennan. 2006. Microbial protein production in the rumen of steers fed low quality forage supplemented with various levels of barley grain or barley grain plus protein. J. Indonesian Trop. Anim. Agric. 31: 1-7.

Moorby, J.M., R. J. Dewhurst, R. T. Evans, and J. L. Danelon. 2006. Effects of Dairy Cow Diet Forage Proportion on Duodenal Nutrient Supply and Urinary Purine Derivative Excretion. J. Dairy Sci. 89:3552-3562.

Pinos-Rodriguez, J. M., S. S. Gonzalez, G. D. Mendoza, R. Barcena, M. A. Cobos, A. Hernandez, and M. E. Ortega. 2002. Effect of exogenous fibrolytic enzyme on ruminal fermentation and digestibility of alfalfa and rye-grass hay fed to lambs. J. Anim. Sci. 80:3016-3020.

Preston, T.R. and R.A. Leng. 1987. Matching Ruminant Production System with available Resources in the Tropics and Sub-Tropics. Penambul Books. Armidale.

Ramli, M.N., Y. Imura, K. Takayama and Y. Nakanishi. 2005. Bioconversion of Sugarcane bagasse with Japanese koji by solid-state fermentation and Its effects on nutritive value and preference in goats. Asian-Aust. J. Anim. Sci. 18( 9):1279-1284.

Wanapat, M., N. Anantasook, P. Rowlinson, R. Pilajun and P. Gunun. 2013. Effect of carbohydrate sources and levels of cotton seed meal in concentrate on feed intake, nutrient digestibility, rumen fermentation and microbial synthesis in young dairy bulls. Asian-Aust. J. Anim. Sci. 26:529-536. 